\title{
Nader Srage, Dialogue des langues
}

\section{Patricia Kottelat}

\section{(2) OpenEdition}

\section{Journals}

\section{Édition électronique}

URL : http://journals.openedition.org/studifrancesi/31008

DOI : 10.4000/studifrancesi.31008

ISSN : 2427-5856

\section{Éditeur}

Rosenberg \& Sellier

\section{Édition imprimée}

Date de publication : 1 avril 2006

Pagination : 214

ISSN : 0039-2944

\section{Référence électronique}

Patricia Kottelat, « Nader Srage, Dialogue des langues », Studi Francesi [En ligne], 148 (XLX | I) | 2006,

mis en ligne le 30 novembre 2015, consulté le 18 avril 2021. URL : http://journals.openedition.org/ studifrancesi/31008; DOI : https://doi.org/10.4000/studifrancesi.31008

\section{Ce document a été généré automatiquement le 18 avril 2021.}

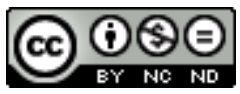

Studi Francesi è distribuita con Licenza Creative Commons Attribuzione - Non commerciale - Non opere derivate 4.0 Internazionale. 


\title{
Nader Srage, Dialogue des langues
}

\author{
Patricia Kottelat
}

\section{RÉFÉRENCE}

NADER SRAGE, Dialogue des langues, Paris, L'Harmattan, 2003, pp. 229.

1 Le Beyrouthin Nader Srage, professeur de linguistique à l'Université Libanaise et membre de la Société Internationale de Linguistique Fonctionnelle (Silf), livre dans son ouvrage une réflexion multiple sur sa passion, la linguistique fonctionnelle, et son domaine de recherches, la diglossie de la langue arabe. Retraçant son parcours personnel dans le domaine de la linguistique fonctionnelle, il décrit ses relations tant académiques que personnelles avec ses deux maitres, André Martinet et Henriette Walter, dont il présente les carrières respectives et leur apport dans cette discipline. L'auteur publie en outre une série d'articles inédits, dont la problématique rejoint celle de ses recherches sur les spécificités de la langue arabe et les phénomènes de diglossie: André Martinet, "Le Gîm arabe", Henriette Walter, "La notion de synchronie dynamique en linguistique fonctionnelle. Application aux interdentales de l'arabe", Nader Srage, «l'interaction des variétés de la langue arabe à Beyrouth». La dernière partie de l'ouvrage est constituée d'entretiens avec d'une part André et Jeanne Martinet et d'autre part avec Henriette Walter, portant sur les spécificités de la linguistique fonctionnelle et son application pour les langues arabe et française, ce qui justifie le titre de Dialogue des langues. 